\title{
Compliance with PECARN head injury decision rules in children under two years old
}

\author{
다 Aydın Gerilmez, M.D., \ Arif Tarkan Çalışaneller, M.D.
}

Department of Neurosurgery, University of Health Sciences, Haydarpaşa Numune Training and Research Hospital, İstanbul-Turkey

\begin{abstract}
BACKGROUND: One of the most common complaints about presentation at the Emergency Department (ED) in childhood is minor head trauma. In recent years, clinical decision rules (CDRs) have been published to assist in determining the need for performing computed tomography (CT) in these patients. The present study aims to investigate the compliance with Pediatric Emergency Care Applied Research Network (PECARN) rules in the decisions for CT examination in children aged below two years old with minor head trauma in our center.
\end{abstract}

METHODS: This retrospective, single-center study was conducted on a patient group aged below two years old, who presented at the ED within 24 hours of a trauma incident and were diagnosed as mild head trauma Glasgow Coma Scale score 14 and I5).

RESULTS: A total of 262 patients were included in this study. Of these patients, 214 (81.7\%) received CT examination, and 48 (18.3\%) patients did not receive any CT examination. None of these 48 patients showed clinically important traumatic brain injury (ci TBI). Among 2 I4 patients who received CT examination, 89 (34\%) patients met the PECARN rules criteria and I25 (47.7\%) patients did not meet PECARN rules criteria. None of the patients who received CT examination and did not meet the PECARN rules criteria showed ci TBI. Among 89 patients who recieved a CT examination and also met the PECARN rules criteria, only 4 (I.5\%) patients showed ci TBI. According to these results, the rate of compliance with PECARN rules in our institution ED was $52.3 \%$.

CONCLUSION: In this study, which was conducted by including all the predictor values of the PECARN guidelines, the rate of compliance with PECARN rules was determined to be very low. Using these rules directly or with modification could establish a starting point for clinicians to reduce the rates of unnecessary CT scans. However, the effects of the clinician's experience, parental expectations, medicolegal constraints and economic factors on the decision making process should not be forgotten.

Keywords: Children; computed tomography; head injury; PECARN.

\section{INTRODUCTION}

One of the most common reasons for presentation at the Emergency Department (ED) in childhood is head trauma. ${ }^{[1]}$ The annual incidence is estimated as $1850 / 100.000$ (0-4 years old), ${ }^{[2]}$ and the majority of cases (80-90\%) are minor trauma. ${ }^{[3,4]}$ While no intracranial pathology develops in most of these patients, clinically important traumatic brain injury (ciTBI) may develop in a small portion despite the head trauma being a minor. Computed tomography (CT) is the standard diagnostic test in the definition of these pathologies. However, the results of studies related to radiation-induced cancer have raised concerns about the application of $\mathrm{CT}$, especially in young patients. ${ }^{[5,6]}$ In addition, there are studies that have related cognitive disorders in adult life to exposure of the infant's brain to ionising radiation. ${ }^{[7]}$ Another negative aspect is the need for sedation during scanning because of agitation in some children. ${ }^{[8,9]}$

Because of these reasons, some clinical decision rules (CDRs) have been published in recent years to assist in the determination of the need for CT in children presented with minor head trauma. By determining the patient group at high risk in respect to intracranial injury, CDRs aim to be

Cite this article as: Gerilmez A, Çalışaneller AT. Compliance with PECARN head injury decision rules in children under two years old. Ulus Travma Acil Cerrahi Derg 2020;26:462-468.

Address for correspondence: Aydın Gerilmez, M.D.

Sağlık Bilimleri Üniversitesi, Haydarpaşa Numune Eğitim ve Araştırma Hastanesi, Beyin ve Sinir Cerrahisi Kliniği, İstanbul, Turkey

Tel: +90 216 - 5423232 E-mail: aydingerilmez@hotmail.com

Ulus Travma Acil Cerrahi Derg 2020;26(3):462-468 DOI: 10.14744/tjtes.2019.36902 Submitted: 23.05.2019 Accepted: 25.10.2019 Online: 13.05.2020

Copyright 2020 Turkish Association of Trauma and Emergency Surgery 
of assistance to clinicians in reducing the need for CT scanning. ${ }^{[0,1]]}$ One of the widely-used guidelines is the Pediatric Emergency Care Applied Research Network (PECARN) rules. PECARN is a reliable guideline in the determination of the high-risk patient group with $100 \%$ sensitivity, $53.8 \%$ specificity, $2 \%$ positive predictive value (PPV) and $100 \%$ negative predictive value (NPV). ${ }^{\left[{ }^{[}\right]}$However, despite all these guidelines, reports that have determined an increase in CT scanning rates in children with head trauma have been published. ${ }^{[12,13]}$

The present study aims to investigate the compliance of CT decisions to PECARN rules in children aged $<2$ years who presented at ED with minor head trauma in our institution.

\section{MATERIALS AND METHODS}

This retrospective, single-centre study was conducted on a paediatric population aged $<2$ years old who presented at the ED units of our hospital because of mild head trauma. Data were collected by examining the medical records for demographic characteristics, trauma history, physical and neurological examination findings and the diagnostic tests applied to the patients. The patients included in this study who presented at ED within 24 hours of the trauma incident and were diagnosed with mild head trauma (GCS 14-15). For the follow-up of patients who had not been applied with neuroimaging, the family was contacted by telephone.

In a one-month duration, a total of 342 patients were identified who were aged $<2$ years and presented at ED with complaints of minor head trauma. Forty-eight patients were excluded from this study given that the medical records were deemed insufficient for evaluation. Of the remaining 294 patients, 10 were excluded as they presented after 24 hours or presented again for the same reason, and a further 22 were excluded as they could not be contacted for follow-up. Finally, an evaluation was made in 262 patients. The study profile is shown in Figure I.

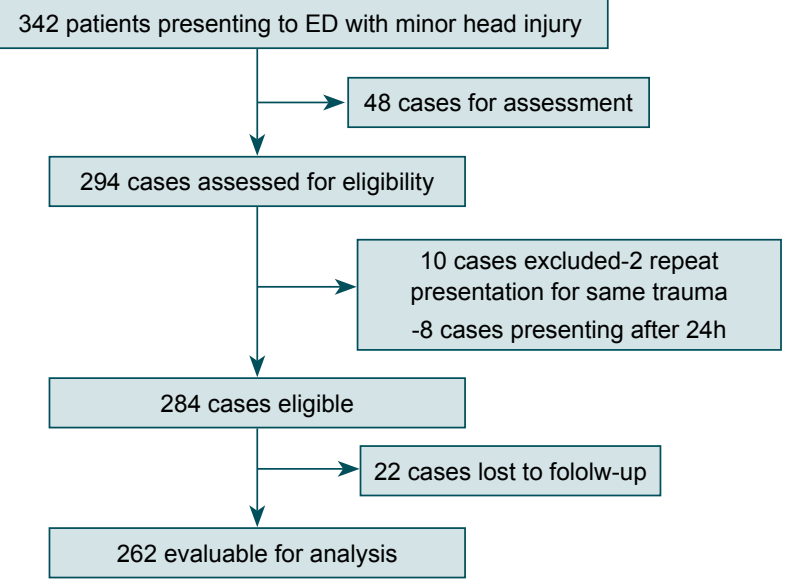

Figure 1. Study profile.
The inclusion and exclusion criteria of the PECARN study for children aged $<2$ years with minor head trauma, the rule-specific predictor variables and outcomes are shown in Table I. Similar to the PECARN study, ciTBI was used as the outcome in this study. ciTBI is defined in Table I.

Table I. Inclusion and exclusion criteria, predictor variables and outcome measures of PECARN clinical decision rules

PECARN $<2$ years old

Inclusion criteria

Age $<2$ years, presenting within $24 \mathrm{~h}$ of head injury

Exclusion criteria Trivial mechanism of injury, defined by ground-level fall or walking or running into stationary objects and no signs or symptoms of head trauma other than scalp abrasions and lacerations Penetrating trauma

Known brain tumours

Pre-existing neurological disorder

Neuroimaging at an outside hospital before transfer

Patient with a ventricular shunt

Patient with a bleeding disorder

GCS score $<14$

Predictor variables (all)

Mechanism of injury

Severe mechanism of injury (MVC with patient ejection, death of another passenger, or rollover; pedestrian or bicyclist without helmet struck by motorised vehicle; falls $>0.9 \mathrm{~m}$; or head struck by high-impact object)

History Loss of consciousness for $\geq 5 \mathrm{~s}$ Not acting normally per parent report GCS score $<15$

Other signs of altered mental status (agitation, somnolence, repetitive questioning, slow response to verbal communication)

Palpable or unclear skull fracture Occipital, parietal, or temporal scalp haematoma

Outcome ciTBI, defined as death from TBI, neurosurgical intervention for TBI, intubation of more than $24 \mathrm{~h}$ for TBI or hospital admission of two nights or more for $\mathrm{TBI}$, associated with $\mathrm{TBI}$ on $\mathrm{CT}$

GCS: Glasgow Coma Scale; ciTBI: Clinically important traumatic brain injury. 
Table 2. Patient characteristic

\begin{tabular}{lcc}
\hline & $\mathbf{n}$ & $\%$ \\
\hline $\begin{array}{l}\text { Demographic characteristics } \\
\text { Boy }\end{array}$ & 158 & 60.3 \\
Girl & 104 & 39.7 \\
Clinician-assigned GCS score & & \\
I4 & 3 & 1.1 \\
I5 & 259 & 98.9 \\
Mechanism of injury & & \\
$\quad$ Fall & 230 & 87.8 \\
Head hit by high impact object & 28 & 10.7 \\
Motor vehicle incident & 3 & 1.1 \\
Suspected non-accidental injury & 1 & 0.49 \\
Outcomes & & \\
Cranial CT & 214 & 81.6 \\
ci TBI & 4 & 1.5 \\
Neurosurgery & 0 & 0 \\
Death & 0 & 0 \\
\hline GCS: Glasgow Coma Scale; CT: Computed tomography; ciTBI: Clinically impor- \\
tant traumatic brain injury.
\end{tabular}

The compliance with the PECARN rules in the decision of CT examination for the patients was examined.

\section{RESULTS}

Two hundred sixty-two patients were included in this study. Gender distribution was I 58 (60.3\%) males and 104 (39.7\%) females. The GCS score on the presentation at ED was 14 in three (I.I\%) patients and 15 in 259 (98.9\%).

The head trauma mechanism was a fall in 230 (87.8\%) cases, the head struck by a high-impact object in 28 (10.7\%), motor vehicle accident-related injury (MVI) in three (I.I\%) cases and suspected non-accidental injury (NAI) in one $(0.49 \%)$ case.
Table 3. Presence of the PECARN predictor variables

PECARN in children aged $<2$ years

\begin{tabular}{lcc}
\hline Predictor variables & $\mathbf{n}$ & $\%$ \\
\hline GCS score $<15$ & 3 & 1.1 \\
Other sign of altered mental status & 18 & 6.9 \\
Scalp hematoma (oksipital, temporal or parietal) & 31 & 11.8 \\
History of loss of consciousness $\geq 5 \mathrm{~s}$ & 4 & 1.5 \\
Acting abnormal per parent & 38 & 14.5 \\
Palpable or unclear skull fracture & 0 & \\
Severe mechanism of injury & 52 & 19.8
\end{tabular}

PECARN: Pediatric Emergency Care Applied Research Network; GCS: Glasgow Coma Scale.

Of the 262 patients, CT was applied to the decision of the clinician in 214 (8I.6\%) cases, ciTBI developed in four (1.5\%) cases, no neurosurgical intervention was applied in any case, and no mortality developed in any patient (Table 2 ).

The most frequently determined PECARN predictor variable was severe mechanism of injury in 52 (19.8\%) patients, GCS score was determined as $<15$ in $3(1.1 \%)$ patients, other signs of altered mental status in 18 (6.9\%), scalp hematoma (occipital, temporal or parietal) in $3 \mathrm{I}$ ( $1 \mathrm{I} .8 \%)$, history of loss of consciousness of $\geq 5 \mathrm{sec}$ in four (1.5\%) and behaving abnormally according to the parent in 38 (I4.5\%) (Table 3).

A total of 262 patients were included in this study. Of these patients, $214(81.7 \%)$ received CT examination, and 48 (18.3\%) patients did not receive any CT examination. None of these 48 patients showed ci TBI. Among 214 patients who received CT examination, 89 (34\%) patients met the PECARN rules criteria and I 25 (47.7\%) patients did not meet PECARN rules criteria. None of the patients who received the CT examination and did not meet the PECARN rules criteria show ci TBI. Among 89 patients who received CT ex-

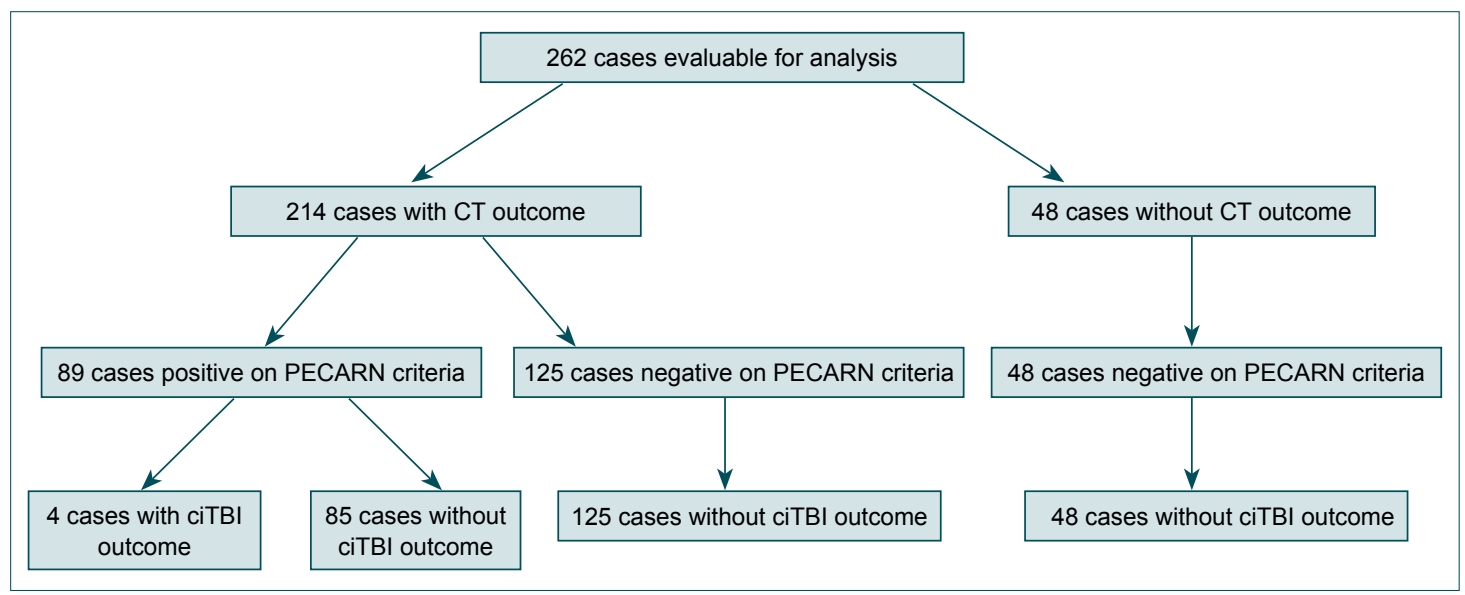

Figure 2. Outcome analysis. 
Table 4. Clinically important traumatic brain injury outcome

\begin{tabular}{lcc}
\hline PECARN in children aged $<2$ years $(\mathbf{n}=\mathbf{2 6 2})$ & $\mathbf{n}$ & $\%$ \\
\hline ciTBI & 4 & 1.5 \\
Positive on criteria & 89 & 34 \\
$\quad$ With outcome $(n)$ & 4 & 1.5 \\
$\quad$ Without outcome $(n)$ & 85 & 32.4 \\
Negative on criteria & 173 & 66 \\
$\quad$ With outcome $(n)$ & 0 & 0 \\
$\quad$ Without outcome $(n)$ & 173 & 66
\end{tabular}

PECARN: Pediatric Emergency Care Applied Research Network; ciTBI: Clinically important traumatic brain injury.

Table 5. CT outcome

\begin{tabular}{lcc}
\hline PECARN in children aged $<2$ years $(\mathbf{n}=\mathbf{2 6 2})$ & $\mathbf{n}$ & $\%$ \\
\hline CT & 214 & 81.7 \\
Positive on criteria & 89 & 34 \\
$\quad$ With outcome $(n)$ & 89 & 34 \\
$\quad$ Without outcome $(n)$ & 0 & 0 \\
Negative on criteria & 173 & 66 \\
$\quad$ With outcome $(n)$ & 125 & 47.7 \\
$\quad$ Without outcome $(n)$ & 48 & 18.3 \\
\hline
\end{tabular}

PECARN: Pediatric Emergency Care Applied Research Network; CT: Computed tomography.

amination and also met the PECARN rules criteria, only four (I.5\%) patients showed ci TBI (Fig. 2). According to these results, the rate of compliance with PECARN rules in our instutition was $52.3 \%$ (Table 4, 5).

\section{DISCUSSION}

CDRs aim to reduce CT scanning as an aid to clinicians in identifying the patient group at high risk of intracranial injury in cases of head trauma. PECARN, Children's Head injury Algorithm for the prediction of Important Clinical Events (CHALICE) and Canadian Assessment of Tomography for Childhood Head injury (CATCH) are guidelines widely used for this purpose. In this study, which was designed to investigate the compliance with these guidelines of the decision for CT in children with minor head trauma aged $<2$ years, the first decision to be made was to determine which of these guidelines would be most suitable for clinical use. Therefore, literature was scanned for extensive cohort studies that have analysed the factors affecting this multifactorial decision. The recent, prospective Paediatric Research in Emergency Departments International Collaborative (PREDICT) study with a patient population of 20.137 was used to make this decision. $^{[14]}$
In the PREDICT study, ciTBI was used as the common outcome measurement, as it was in the original PECARN study, to provide a more valid outcome in respect of family, clinician and the healthcare system, comparing the three CDRs of outcome measurements, inclusion and exclusion criteria, which are different. ${ }^{[14]}$

As the primary outcome in the CATCH study is death and neurosurgical intervention, these results are very limited, and it is very risky in respect of overlooking trauma-related morbidity. ${ }^{[14,15]}$ On the other hand, the outcome of the CHALICE study includes CT abnormalities, which may not be clearly related to clinical results. ${ }^{[14,16]}$

The comparative cohort in the PREDICT study was similar to that of our study as it included paediatric patients who presented within 24 hours with a mild injury following trauma.

CDRs must have very high sensitivity in the determination of cranial injuries and high NPV in the identification of patients at low risk. Similar to the PECARN original derivation study, in the PREDICT study with an extensive comparative cohort, ciTBI was determined to have high sensitivity in the prediction in both age years (<2 years $100 \%$, $>2$ years $99.2 \%$ ). CATCH rules sensitivity was determined as $91.9 \%$, similar to the derivation study. When CHALICE predictive values were used, sensitivity was $92.5 \%$. Both CATCH (70.4\%) and CHALICE (78.6\%) have higher specificity than PECARN (59.1\%). ${ }^{[14]}$

In their study, Bozan et al. ${ }^{[17]}$ compared PECARN and CATCH clinical decision rules in children minor head trauma and reported that the sensitivity of PECARN was $95(95 \% \mathrm{Cl} 72-$ 100) and specificity was 53 (95\% Cl 47-60\%), whereas the sensitivity of CATCH was $48(95 \% \mathrm{Cl} 25-71 \%)$, and specificity was 83 (95\% Cl 79-88\%). Therefore, they concluded that although both PECARN and CATCH where effective in the clinical decision making for CT scanning, PECARN was more useful for emergency services due to higher sensitivity. In another study, Gokharman et al. ${ }^{[18]}$ studied PECARN rules on the basis of cost and effectiveness. They found that PECARN rules could successfully predict pathology and decrease resource waste and exposure to radiation in pediatric head traumapatients.

Even though there is a balance between sensitivity and specificity, it is difficult to accept increased specificity at the cost of reduced sensitivity, as the reduced sensitivity may cause intracranial traumatic lesions that require surgical intervention to be overlooked, thereby resulting in morbidity and mortality. Therefore, for both the patient and clinician, priority is given to high sensitivity. ${ }^{[14]}$

For all these reasons, compliance with the CT decisions according to the PECARN rules was selected in this study. 
In our study, the GCS score on the presentation at ED was determined as 14 in three (I.I\%) patients and 15 in 259 (98.9\%) patients, while the rates in the PECARN validation study cohort were GCS 14 in $3.2 \%$ and GCS 15 in $96.8 \% .^{[1]}$ In the PREDICT study, the rate of patients with GCS I 4 was $2.9 \%$ and GCS 15 was $95.4 \% .^{[14]}$

The head trauma mechanism was a fall in 230 (87.8\%) cases, the head struck by a high-impact object in 28 (10.7\%) cases, $\mathrm{MVI}$ in three (I.I\%) cases and suspected NAI in one $(0.49 \%)$ case. The most common mechanism of head trauma was determined as a fall because this patient group was aged $<2$ years and at the developmental stage of learning to walk. In the PREDICT study of the current study cohort, the mechanisms of injury most determined were fall-related head injury (70.1\%), followed by head struck by high-impact object or projectile $(6.6 \%){ }^{[14]}$

Of the PECARN predictor variables used in our study to investigate the high-risk group in respect of ciTBI development, the most commonly determined variable was severe mechanism of injury in $52(19.8 \%)$ patients, GCS score was determined as < 15 in 3 ( $1.1 \%$ ) patients, other signs of altered mental status in 18 (6.9\%), scalp hematoma (occipital, temporal or parietal) in 31 ( $11.8 \%)$, history of loss of consciousness of $\geq 5 \mathrm{sec}$ in four ( $1.5 \%)$ and behaving abnormally according to the parent in 38 (14.5\%) patients.

In the PREDICT study, the PECARN predictor variables were determined as a severe mechanism of injury $(20.5 \%)$, scalp hematoma (12.3\%), behaving abnormally according to the parent $(12.1 \%)$, other signs of altered mental status in I8 (6.3\%), history of loss of consciousness of $\geq 5 \mathrm{sec}(3 \%)$, palpable or unclear skull fracture $(2.9 \%)$ and GCS score $<15$ (2.7\%), respectively. ${ }^{[14]}$

Of the 89 patients in our study who met the criteria according to the PECARN rules, ciTBI was determined in four patients. In the 173 patients who did not meet the criteria, no ciTBI was determined. In the PREDICT study of children aged $<2$ years, ciTBI was determined in 42 of 20149 patients who met the criteria, and no ciTBI was reported in the 2957 patients who did not meet the criteria. Sensitivity was reported as $100 \%$ (95\% Cl, 91.6-100.0), specificity as 59.4\% (95\% Cl, 57.5-60.5), PPV as $2.0 \%(1.5-2.7)$, and NPV as $100 \%(99.0-100) .{ }^{[14]}$ In our study, sensitivity, specificity and PPV could not be statistically evaluated as the sample volume was insufficient. However, ciTBI did not develop in any patient that did not meet the criteria was similar to the findings of the PREDICT study.

When the PECARN rules were applied to our study population, although CT examination was approved for 89 (34\%) patients, it was determined that CT was applied to 214 (8I.6\%) of the total 262 patients on the decision of the clinician. In the PREDICT study, CT was reported to be performed $10.5 \%$ of the patients. However, with the application of $\mathrm{CATCH}$ and
CHALICE to this comparative cohort, these rates were reported to be $22.0 \%$ and $30.2 \%$, respectively, thus would show an increase of $150 \%-250 \%$.

Determination of predicted CT rates is more difficult in cohorts applied with the PECARN guidelines because some of the low-risk patients may need either CT scanning or clinical observation. When all the PECARN predictors were included in the PREDICT of children aged $<2$ years $(n=40 \mathrm{II})$, it was reported that 1872 patients met the criteria. This provided a CT scan rate of $46.7 \%$. In the original PECARN validation study, the CT scan rate was reported as $35.3 \% .^{[1]}$ This rate was $30.2 \%$ in the CATCH study (performance of the four high-risk factors relation to need for neurological intervention) ${ }^{[15]}$ and $14.1 \%$ in the CHALICE study (prediction of important clinical events rule). ${ }^{[16]}$

In a retrospective, multicentre study of children aged $<2$ years with a mild head injury, Velasco et al. ${ }^{\left[{ }^{[9]}\right.}$ reported that the rate of compliance to PECARN guidelines was $>50 \%$ in only three of four hospitals and the most successful compliance rate was $70 \%$.

In a study by Tama et al.," ${ }^{[20]}$ no difference was seen between doctors of different specialties in respect of compliance to PECARN criteria in paediatric patients with acute head trauma and general compliance was reported as $93 \%$.

Kobe et al. ${ }^{[21]}$ reported that the rate of CT scans decreased from $56 \%$ to $33 \%$ after the use of PECARN in pediatric acute head trauma cases, no ciTBI was overlooked and the discharge rate increased from $58 \%$ to $81 \%$.

Studies that have evaluated the effects of the application of PECARN guidelines have shown an effective reduction in CT rates in centers with high $C T$ use and no increase in centers with low CT rates. ${ }^{[22]}$

In our study, when the PECARN rules were applied, the CT rate was $34 \%$, which is similar to the original PECARN study. However, the actual rate of CT scans taken on the decision of the clinician was $81.7 \%$. CT scanning was applied to all 89 patients for whom it was deemed necessary according to the PECARN rules. However, additional 125 patients who did not require $C T$, according to PECARN, also received $C T$ examination. CT scan was not performed in only 48 patients in our study group. Thus, in a total of 137 patients ( 89 patients with CT outcome and 48 patients without CT outcome), the decision was made in conformity with the PECARN rules. When all the predictors were included, including in the whole population those referred to as low-risk in the PECARN guideline, the rate of compliance to the PECARN rules was $52.3 \%$.

\section{Conclusion}

In this study, which was conducted by including all the predic- 
tor values of the PECARN guidelines, the rate of compliance with PECARN rules was determined to be very low. Using these rules directly or with modification could establish a starting point for clinicians to reduce the rates of unnecessary CT scans. However, the effects of the clinician's experience, parental expectations, medicolegal constraints and economic factors on decision making process should not be forgotten.

\section{Ethics Committee Approval: Approved by the local} ethics committee.

\section{Peer-review: Internally peer-reviewed.}

Authorship Contributions: Concept: A.G., A.T.Ç.; Design: A.G., A.T.Ç.; Supervision: A.G., A.T.Ç.; Fundings: A.G., A.T.Ç.; Materials: A.G., A.T.Ç.; Data: A.G., A.T.Ç.; Analysis: A.G., A.T.Ç.; Literature search: A.G., A.T.Ç.; Writing: A.G., A.T.Ç.; Critical revision: A.G., A.T.Ç.

Conflict of Interest: None declared.

Financial Disclosure: The authors declared that this study has received no financial support.

\section{REFERENCES}

1. Kuppermann N, Holmes JF, Dayan PS, Hoyle JD Jr, Atabaki SM, Holubkov R, et al; Pediatric Emergency Care Applied Research Network (PECARN). Identification of children at very low risk of clinicallyimportant brain injuries after head trauma: a prospective cohort study. Lancet 2009;374:1160-70.

2. McKinlay A, Grace RC, Horwood LJ, Fergusson DM, Ridder EM, MacFarlane MR. Prevalence of traumatic brain injury among children, adolescents and young adults: prospective evidence from a birth cohort. Brain Inj 2008;22:175-81. [CrossRef]

3. Ayr LK, Yeates KO, Taylor HG, Browne M. Dimensions of postconcussive symptoms in children with mild traumatic brain injuries. J Int Neuropsychol Soc 2009;15:19-30. [CrossRef]

4. Crowe LM, Anderson V, Catroppa C, Babl FE. Head injuries related to sports and recreation activities in school-age children and adolescents: data from a referral centre in Victoria, Australia. Emerg Med Australas 2010;22:56-61. [CrossRef]

5. Faulkner K, Moores BM. Radiation dose and somatic risk from computed tomography. Acta Radiol 1987;28:483-8. [CrossRef]

6. Brenner DJ, Hall EJ. Computed tomography--an increasing source of radiation exposure. N Engl J Med 2007;357:2277-84. [CrossRef]

7. Hall P, Adami HO, Trichopoulos D, Pedersen NL, Lagiou P, Ekbom A, et al. Effect of low doses of ionising radiation in infancy on cognitive function in adulthood: Swedish population based cohort study. BMJ 2004;328:19. [CrossRef]

8. Vade A, Sukhani R, Dolenga M, Habisohn-Schuck C. Chloral hydrate sedation of children undergoing CT and MR imaging: safety as judged by American Academy of Pediatrics guidelines. AJR Am J Roentgenol 1995;165:905-9. [CrossRef]

9. Conners GP, Sacks WK, Leahey NF. Variations in sedating uncooperative, stable children for post-traumatic head CT. Pediatr Emerg Care 1999;15:241-4. [CrossRef]
10. Lyttle MD, Crowe L, Oakley E, Dunning J, Babl FE. Comparing CATCH, CHALICE and PECARN clinical decision rules for paediatric head injuries. Emerg Med J 2012;29:785-94. [CrossRef]

11. Pickering A, Harnan S, Fitzgerald P, Pandor A, Goodacre S. Clinical decision rules for children with minor head injury: a systematic review. Arch Dis Child 2011;96:414-21. [CrossRef]

12. Stanley RM, Hoyle JD Jr, Dayan PS, Atabaki S, Lee L, Lillis K, et al; Pediatric Emergency Care Applied Research Network (PECARN). Emergency department practice variation in computed tomography use for children with minor blunt head trauma. J Pediatr 2014;165:1201-6. e2. [CrossRef]

13. Klassen TP, Reed MH, Stiell IG, Nijssen-Jordan C, Tenenbein M, Joubert $\mathrm{G}$, et al. Variation in utilization of computed tomography scanning for the investigation of minor head trauma in children: a Canadian experience. Acad Emerg Med 2000;7:739-44. [CrossRef]

14. Babl FE, Borland ML, Phillips N, Kochar A, Dalton S, McCaskill M, et al; Paediatric Research in Emergency Departments International Collaborative (PREDICT). Accuracy of PECARN, CATCH, and CHALICE head injury decision rules in children: a prospective cohort study. Lancet 2017;389:2393-402. [CrossRef]

15. Osmond MH, Klassen TP, Wells GA, Correll R, Jarvis A, Joubert G, et al; Pediatric Emergency Research Canada (PERC) Head Injury Study Group. CATCH: a clinical decision rule for the use of computed tomography in children with minor head injury. CMAJ 2010;182:341-8.

16. Dunning J, Daly JP, Lomas JP, Lecky F, Batchelor J, Mackway-Jones K; Children's head injury algorithm for the prediction of important clinical events study group. Derivation of the children's head injury algorithm for the prediction of important clinical events decision rule for head injury in children. Arch Dis Child 2006;91:885-91. [CrossRef]

17. Bozan Ö, Aksel G, Kahraman HA, Giritli Ö, Eroğlu SE. Comparison of PECARN and CATCH clinical decision rules in children with minor blunt head trauma. Eur J Trauma Emerg Surg 2019;45:849-55. [CrossRef]

18. Gökharman FD, Aydın S, Fatihoğlu E, Koşar PN. Pediatric Emergency Care Applied Research Network head injuryprediction rules: on the basis of cost and effectiveness. Turk J Med Sci 2017;47:1770-7. [CrossRef]

19. Velasco R, Arribas M, Valencia C, Zamora N, Fernández SM, Lobeiras A, et al. Adecuación del manejo diagnóstico del traumatismo craneoencefálico leve en menores de 24 meses a las guías de práctica clínica de PECARN y AEP [Compliance with the PECARN and AEP guidelines in diagnostic approach of mild head trauma in patients younger than 24 months old]. An Pediatr (Barc) 2015;83:166-72. [CrossRef]

20. Tama M, Andharia N, Bufano C, Greenstein J, Khodorkovsky B. Does Specialty Training and Practice Setting Affect Adherence to the Pediatric Emergency Care Applied Research Network Criteria for Pediatric Head Trauma? Pediatr Emerg Care. 2017 Nov 27. doi: 10.1097/ PEC.0000000000001364. [Epub ahead of print]. [CrossRef]

21. Kobe IO, Qureshi MM, Hassan S, Oluoch-Olunya DL. The impact of the introduction of PECARN head CT rules on the utilisation of head CT scans in a private tertiary hospital in Sub-Saharan Africa. Childs Nerv Syst 2017;33:2147-52. [CrossRef]

22. Bressan S, Romanato S, Mion T, Zanconato S, Da Dalt L. Implementation of adapted PECARN decision rule for children with minor head injury in the pediatric emergency department. Acad Emerg Med 2012;19:801-7. [CrossRef] 
ORİJINAL ÇALIŞMA - ÖZET

\section{İki yaşından küçük çocuklarda PECARN kafa kravması klinik karar kurallarına uyum}

\section{Dr. Aydın Gerilmez, Dr. Arif Tarkan Çalışaneller}

Sağlık Bilimleri Üniversitesi, Haydarpaşa Numune Eğitim ve Araştırma Hastanesi, Beyin ve Sinir Cerrahisi Kliniği, İstanbul

AMAÇ: Çocukluk çağında acil servise başvuruların yaygın nedenlerinden biri çoğunluğu minör olan kafa travmalarıdır. Bu hastalarda BT (bilgisayarlı tomografi) çekim ihtiyacının belirlenmesine yardımcı olması amacıyla son birkaç yılda bazı klinik karar kuralları yayınlanmıştır. Bu çalışmada iki yaşından küçük minör kafa travmalı çocuklarda BT çekim kararlarında PECARN (Pediatric Emergency Care Applied Research Network) kurallarına uyum araştırıldı.

GEREÇ VE YÖNTEM: Bu geriye dönük, tek merkezli çalışma iki yaşından küçük, travma oluşumunu takip eden ilk 24 saat içinde acil servise ilk başvurusunu yapan ve başvuru Glaskow Koma Skala skorları 14 ve 15 olan hafif kafa travmalı hasta grubunda yürütüldü.

BULGULAR: Çalışmaya toplam 262 hasta dahil edildi. Bu hastaların 2।4’üne (\%8।.7) BT incelemesi yapıldığı, 48'ine (\%।8.3) yapılmadığı saptandı. BT taraması yapılmayan 48 hastanın hiçbirinde klinik olarak önemli travmatik beyin hasarı gelişmediği belirlendi. BT incelemesi yapılan 2 I 4 hastadan 89'unda (\%34) BT çekim kararı verilirken PECARN kurallarına uyulduğu, 125 (\%47.7) hastada bu kurallarına uyulmadığı saptandı. PECARN kriterlerini karşılamayan ve BT incelemesi yapılan hastaların hiçbirinde klinik olarak önemli travmatik beyin hasarı gelişmediği, PECARN kriterlerini karşılayan 89 hastanın sadece dördünde (\%।.5) klinik olarak önemli travmatik beyin hasarı geliştiği saptandı. Bu sonuçlara göre, kurumumuzda PECARN kurallarına uyum oranı \%52.3 idi.

TARTIŞMA: PECARN kılavuzunun tüm belirleyici kriterleri dahil edilerek yürütülen çalışmamızda PECARN kurallarına uyum oranının düşük olduğu saptanmıştır. Gereksiz BT çekim oranlarının düşürülmesi için klinisyenlerin bu kuralları direkt veya modifiye ederek kullanması iyi bir başlangıç noktası oluşturabilir. Fakat klinisyen deneyimi, ebeveyn beklentisi, medikolegal çekinceler ve ekonomik faktörlerin bu karar üzerindeki etkisi unutulmamalıdır. Anahtar sözcükler: Bilgisayarlı tomografi; çocuk; kafa travması; PECARN.

Ulus Travma Acil Cerrahi Derg 2020;26(3):462-468 doi: 10.14744/tjtes.2019.36902 